\title{
Nonprofit Financial Resilience: Recovery from Natural Disasters
}

\author{
Xintong Chen ${ }^{1}$ (D)
}

Accepted: 4 September 2021 / Published online: 28 September 2021

(C) International Society for Third-Sector Research 2021

\begin{abstract}
Nonprofits operate in increasingly complex and turbulent environments. However, few studies have explored nonprofits' resilience during natural disasters. This study uses Hurricane Katrina as a case study to explore whether nonprofits can regain their original financial performance after significant natural disasters and what organizational capacities and abilities influence their ability to bounce back. The results show that recovery is slow, taking between three and five years for half of the nonprofits in the sample. Recovery depends on factors such as organizational size, equity, surplus, and commercial revenue. This study enriches the nonprofit financial health literature and reveals that the factors associated with financial resilience are different from those that predict financial vulnerability.
\end{abstract}

Keywords Financial health $\cdot$ Financial resilience $\cdot$ Natural disasters $\cdot$ Nonprofits

\section{Introduction}

Nonprofits operate in increasingly complex and turbulent environments. Disasters, regardless of their magnitude and severity, can overwhelm an organization's capabilities to survive and thrive (Jung \& Song, 2015). For example, some nonprofits lose the physical capital necessary to maintain operations. Auer, (2006) shows that about $30 \%$ of nonprofits have experienced damage to their facilities, and their office supplies were either destroyed or lost after

Xintong Chen

xintong.chen@sjsu.edu

1 San Jose State University, San Jose, USA
Hurricane Katrina. In a survey by the Mississippi Center for Nonprofits, $77 \%$ of the respondents reported significant building damage after Hurricane Katrina (Pipa, 2006). Additionally, $67 \%$ indicated they had to dismiss paid and volunteer staff (Pipa, 2006).

Starting from Tuckman and Chang, (1991), a large number of nonprofit studies have focused on the factors that help nonprofits reduce their financial vulnerability (Chen, 2021; Geller et al., 2010; Joseph, 2011; Lin \& Wang, 2016; Park \& Mosley, 2017). Indeed, the financial vulnerability of a nonprofit is often associated with its organizational characteristics and financial ratios. Another intriguing question for nonprofit researchers and practitioners is: how can nonprofits recover if they are already in a poor financial state? Organizational recovery from adverse events, evaluated in terms of organizational resilience, is more widely studied in relation to the for-profit sector (Linnenluecke, 2017; Meyer, 1982; Staw et al., 1981; Sutcliffe \& Vogus, 2003). However, unlike the business sector, the nonprofit sector has a nondistribution constraint, is supported by donations, and is accountable to the public (Salamon, 2004). These characteristics lead to different priorities and strategies when responding to similar risks or uncertainties; consequently, the results of business literature do not translate perfectly to the nonprofit context. Accordingly, this study analyzes organizational resilience in the nonprofit sector, making an important and timely contribution to the literature, especially in light of the effects of the COVID-19 pandemic on nonprofits.

I especially explore how nonprofits that are in poor financial health can recover after a disaster. Particularly, I examine: 1) whether and when nonprofits regain their original financial performance after significant natural disasters, and 2) what factors help nonprofits in this process. 


\section{Financial Resilience}

Nonprofit financial health has been studied for nearly 30 years, ever since Tuckman and Chang (1991) discussed nonprofits' financial vulnerability. Most studies focus on how nonprofits can reduce their financial vulnerability (Chang \& Tuckman, 1994; Greenlee \& Trussel, 2000; Hager, 2001; Keating, Fischer, Gordon, \& Greenlee, 2005; Trussel, 2002). Less explored is how nonprofits bounce back to their original performance when they are already in poor financial health owing to internal or external reasons. This study borrows the concept of organizational resilience from the business sector to describe the financial recovery of nonprofits. Similar to Staw et al., (1981) and Meyer, (1982), I define nonprofit financial resilience as the ability, or capacity, of an organization to bounce back to at least its original financial performance level after a disruptive event.

To understand organizational resilience, nonprofit financial performance must be quantitatively measured, such as through assets- (Keating et al., 2005; Searing, 2018), revenue- (Callen et al., 2003; Carroll \& Stater, 2009; Keating et al., 2005; Lin \& Wang, 2016; Park \& Mosley, 2017), and expense-related measures (Keating et al., 2005; Lin \& Wang, 2016; Never, 2011). Prentice, (2016a) reviews more than 70 financial performance measures to show that financial performance is a complex issue and cannot be captured by single measures. He summarizes four common measures of financial performance-liquidity, solvency, margin, and profitability—but does not determine the "correct" way to measure them.

To increase the validity of their study, scholars often choose more than one measure of performance based on their research focus and context. Keating et al., (2005) use four different measures (insolvency risk, financial disruptions, funding disruptions, and program disruptions) associated with nonprofits' ability to carry out their mission. Lin and Wang (2016) use changes in revenue and expense to measure financial resilience in the context of the Great Recession. Searing, (2018) uses the change in net assets to measure the financial recovery of nonprofits. Paarlberg and his colleagues (2012) use spending and saving ratios to study how market structure affects the fiscal health of nonprofits.

This study uses the change in total expenses and net assets to measure nonprofit financial performance in a natural disaster context. Rebound from revenue disruption is not chosen, although it is frequently used in nonprofit research in examining the response to economic downturns, because economic downturns and natural disasters have different effects on nonprofits. Specifically, economic downturns harm nonprofit revenues, while natural disasters intensify nonprofit service demands and cause physical damage. Thus, it is more valuable to measure how nonprofits rebound from financial and service disruptions, to examine their financial performance in a disaster context. Total expense is chosen to measure service disruption because "an organization's expenses are a more contemporaneous measure of its presence in a community" (Never, 2014, p. 70); moreover, total expense shows whether nonprofits can meet their community's needs after being affected by natural disasters. Net assets are chosen to measure financial disruption because lower net assets or decreases in net assets indicate future insolvency and lower long-term financial sustainability (Bowman, 2011; Keating et al., 2005; Lam \& McDougle, 2016).

\section{Factors Influencing Nonprofit Resilience}

\section{Pre-disaster Financial Resources}

Nonprofits highly depend on the external environment for financial resources compared with government agencies and for-profit organizations (Carroll \& Stater, 2009; Tuckman \& Chang, 1991). Financial resources are important for nonprofits to maintain their operations and provide mission-related services (Never, 2014) as well as to handle increasing service demands and offset the loss of staff, offices, and supplies during disasters (Sylves, 2008). Smith, (2012) finds that nonprofits need to have enough financial resources to support them for at least three months after a disaster. Nonprofits without sufficient funds must either generate revenue to meet the new needs or wait for help from other organizations, which may impede recovery.

Hypothesis 1 Nonprofits with higher levels of pre-disaster financial resources are more likely to bounce back after a disaster compared with nonprofits with lower pre-disaster financial resource levels.

\section{Revenue Structure}

Modern portfolio theory (MPT) holds that the diversification of financial portfolios enables investors to earn the same expected returns of investment but with less risk (Markowitz, 1952). Particularly, according to the MPT, nonprofits should diversify their revenue portfolios. Nonprofits usually generate revenue from multiple sources. Relying on a single source increases financial volatility compared to obtaining revenue from multiple and diverse sources. The latter approach allows nonprofits to develop fallback plans when one revenue source fails, provided the failure is not caused by a system risk (such as economic 
downturns, which affect all revenue sources) (Kearns, 2007; Lin \& Wang, 2016).

Revenue concentration is also positively related to nonprofit financial vulnerability (Hager, 2001; Keating et al., 2005; Tuckman \& Chang, 1991). Carroll and Hannan (2009) find that a more diversified revenue structure increases nonprofit financial stability and reduces volatility. A stable financial environment enables nonprofits to focus on recovering from and responding to the disaster, satisfying community needs, and rebuilding damaged facilities.

Hypothesis $2 a$ Nonprofits with greater revenue diversification are more likely to bounce back after a disaster than nonprofits with less revenue diversification.

MPT holds that different combinations of assets are associated with different levels of expected returns and risk (Markowitz, 1952). For nonprofits, this means different combinations of revenue sources are associated with different levels of financial performance. Nonprofits usually obtain revenue from three major streams: public contributions (government funding and private contributions), earned income, and investments. Different revenue streams have different effects on organizational resilience because each stream has its own characteristics (Carroll \& Stater, 2009; Froelich, 1999). The donation-based stream has high administrative costs and is sensitive to environmental change, which leads to difficulties in planning and maintaining programs (Froelich, 1999; Grønbjerg, 1993). By contrast, commercial nonprofits tend to have lower administrative costs and greater financial stability. Thus, their operations and programs are less likely to be disrupted by natural disasters. Therefore, different combinations of revenue streams can affect organizational resilience.

Hypothesis $2 b$ Nonprofits with greater commercial revenue are more likely to bounce back after a disaster than nonprofits with less commercial revenue.

\section{Organizational Characteristics}

The liability of newness explains the correlation between organizational age and performance. According to Stinchcombe and March, (1965), compared with more established organizations, newly established organizations have higher risks of mortality because of their lack of social capital, financial resources, or routines to contribute to the efficiency and legitimacy essential for survival. In a natural disaster context, newly established nonprofits have fewer opportunities to recover. First, they are less exposed to natural disasters, and, thus, possess little coping experience. A lack of experience increases the likelihood of postdisaster failure. Such nonprofits also often lack the financial resources to recover from adverse events. Third, older organizations usually have more collaborators and allies (Guo \& Acar, 2005), which makes them more resilient (Kapucu, 2006).

Hypothesis $3 a$ Older nonprofits are likely to bounce back quicker after a disaster than younger nonprofits.

Similar to the liability of newness, the liability of smallness also predicts organizational performance. Smaller organizations have fewer social and financial resources. Most nonprofit financial literature agrees that organizational size affects financial performance (De AndrésAlonso, Garcia-Rodriguez, \& Romero-Merino, 2015; Keating et al., 2005; Trussel, 2002). Smaller organizations are also more vulnerable during economic downturns. Joseph (2011) finds that smaller organizations (based on the number of employees and assets) had lower fundraising ability than larger ones during the Great Recessions. Lin and Wang, (2016) show that it is challenging for smaller organizations to recover from economic downturns because they find it difficult to search for new funding sources and maintain multiple fund relationships.

In a disaster context, smaller nonprofits often lack the financial capacity to meet service demands and organizational needs (Trussel, 2002). They may find it difficult to identify alternative funding sources during disasters. First, they may not have professional staff to raise funds and manage new funding relationships during emergencies. It is easier for larger organizations to attract donations in a disaster context because of their better reputation among donors. For example, during Hurricane Katrina, most disaster response donations flowed to large national organizations with high reputations, such as the Red Cross (Smith, 2012). Small organizations are often ignored by donors, especially those outside their communities (Smith, 2012).

Hypothesis $3 b$ Larger nonprofits are more likely to bounce back after a disaster than are smaller nonprofits.

\section{Data and Method}

\section{Study Context}

Hurricane Katrina remains one of the most destructive natural disasters in the history of the USA (Smith, 2006). It caused devastating damage along the Gulf coast, especially around New Orleans, resulting in property damage worth $\$ 120$ billion and over 1,800 deaths (Donahue \& O'Keefe, 2007). Nonprofits were widely affected by Hurricane Katrina (Chikoto et al., 2013). Approximately 93\% of all nonprofits cut back on their services, $77 \%$ experienced damage to physical facilities, and $67 \%$ lost staff or 
volunteers (Pipa, 2006). Finally, recovery is a long-term process. Nonprofits' recovery from Hurricane Katrina can now be tracked for at least ten years. Specifically, I use the Federal Emergency Management Agency (FEMA) Katrina declaration ${ }^{1}$ to identify affected locations. All counties in Louisiana and Mississippi, 22 counties in western Alabama, and 11 counties in Florida were declared by FEMA as having been physically affected by Hurricane Katrina.

\section{Sample}

Nonprofit data are obtained from NCCS Core files, which contain information on the Internal Revenue Service Form 990 series. To study the entire recovery process of nonprofits, data from 2004 to 2013 were selected, so as to include enough years to track pre- and post-disaster performance. The disaster occurs in 2005 and 2004 is used as the recovery baseline. This panel dataset initially included 3,521,353 observations. Nonprofits located outside the disaster-affected regions declared by the FEMA were removed. Then, given the diverse nature of the nonprofit sector, only subsectors likely to actively participate in disaster response were identified by their National Taxonomy of Exempt Entities codes and retained, and all other nonprofits were removed from the dataset. Table 1 shows the service fields selected, while Table 2 presents the data cleaning process.

First, all fiscal variables were adjusted to the 2005 currency value for inflation using the Consumer Price Index. Second, following Calabrese, (2011), nonprofit organizations with missing or incorrect rule dates were removed from the sample. Third, following Calabrese, (2011), nonprofit observations with revenues and expenses of less than zero were dropped. Finally, nonprofits that experienced a decrease in financial performance after Hurricane Katrina were selected for the final dataset. Since the financial performance of nonprofits can be measured by either total expense or net assets, two separate sample datasets were developed. The total expense sample only includes nonprofits with a $>10 \%$ decrease in total expenses between 2004 and 2006 (Table 3). The net assets sample only includes nonprofits with a $>10 \%$ decrease in total assets between 2004 and 2006 (Table 4).

\section{Variables}

This study includes two dependent variables (DV), six independent variables (IV), and several control variables.

\footnotetext{
${ }^{1}$ For more information, see https://www.fema.gov/disaster/1602, https://www.fema.gov/disaster/1603, https://www.fema.gov/es/dis aster/1604, and https://www.fema.gov/disaster/1605.
}

\section{[DV] Total Expense Recovery}

This is calculated as the difference between the total expense in fiscal year $j(j=2007,2008,2013)$ and 2004 (pre-disaster year) divided by the total expense in 2004 . This indicator was then transformed into a dummy variable which is given the value of 1 (recovered from the disaster's effects) if this indicator is larger than -0.1 , and 0 vice versa. The threshold is chosen to be $10 \%$ because, according to Park and Mosley, (2017), a performance fluctuation within $10 \%$ is assumed to be normal for nonprofits.

Total expensere covery $=\frac{\text { total }_{\text {expense }} \text { - } \text { total }_{\text {expense }} \text { 2004 }}{\text { total expense }_{2004}} ;$ $j=2007,2008, \ldots, 2013$

\section{[DV] Net asset Recovery}

Nonprofits may lose assets, such as buildings and equipment, in a disaster. The reduction in total assets may also reduce net assets. The net asset recovery variable is calculated as the difference between the net assets in fiscal year $\mathrm{j}(\mathrm{j}=2007,2008, \ldots$ 2013) and 2004 (pre-disaster year) divided by the total net assets in 2004. This indicator was then transformed into a dummy variable which is given the value of 1 (recovered from the disaster's effects) if this indicator is larger than -0.1 , and 0 vice versa.

Total net asset recovery $=\frac{\text { Total net asset }_{j}-\text { Total net asset }_{2004}}{\text { Total net asset }_{2004}}$; $j=2007,2008, \ldots, 2013$

\section{[IV] Equity Ratio}

The equity ratio is an indicator of the pre-disaster financial resources, calculated as the ratio of net assets to total revenue. According to Tuckman and Chang, (1991), equity can help nonprofits borrow from the capital market and can also be converted into cash to offset revenue shocks; moreover, nonprofits can sell unrestricted liquid funds to meet their needs and increase services that use restricted funds. Therefore, nonprofits with higher equity ratios are considered to have higher levels of pre-disaster financial resources. I use the pre-disaster equity ratio (in 2004) to indicate pre-disaster financial resources.

\section{[IV] Surplus}

Surplus is the total operating margin, measured as total revenue less total expense divided by total revenue 
Table 1 Selected service fields

\begin{tabular}{llr}
\hline Service fields (NTEE-CC) & Observations in final potential sample & Percent of total (\%) \\
\hline Health care (E) & 4996 & 19.78 \\
Mental health and crises intervention (F) & 1890 & 27.26 \\
Crime and legal-related (I) & 1485 & 33.14 \\
Employment (J) & 765 & 36.17 \\
Food, agriculture, and nutrition (K) & 568 & 38.42 \\
Housing and shelter (L) & 3953 & 15.57 \\
Public safety, disaster preparedness \& relief (M) & 856 & 54.07 \\
Human services (P) & 10,744 & 57.46 \\
Total & 25,257 & 100.00 \\
\hline
\end{tabular}

Table 2 Sample selection and data cleaning

\begin{tabular}{lc}
\hline Beginning sample size (include all nonprofit observations in NCCS Core files from 2004 to 2013) & $3,521,353$ \\
\hline Less nonprofits not in disaster-affected counties & $-3,416,282$ \\
Less nonprofits not corresponding to the NTEE-CC codes listed in Table 1 & $-67,922$ \\
Less nonprofits with missing or incorrect rule dates & -199 \\
Less nonprofits with negative assets, expenses, revenues, and contributions & -781 \\
Less nonprofits with incorrectly calculated equity ratio surplus (outliers) & 10,907 \\
Less nonprofits without FIPS code & -5 \\
Final potential sample size & 25,257
\end{tabular}

Table 3 Sample selection and data cleaning for total expense recovery

Table 4 Sample selection and data cleaning for net assets recovery

\begin{tabular}{ll}
\hline Final potential sample size & 25,257 \\
\hline Less nonprofits without at least a 10\% decrease in total expense between 2006 and 2004 & $-19,085$ \\
Less observations before 2007 for expense recovery sample & -2208 \\
Less observations after recovery & -1511 \\
Less observations with missing values & -1900 \\
Final total expense sample size & -553 \\
\hline
\end{tabular}

\begin{tabular}{ll}
\hline Final potential sample size & 25,257 \\
\hline Less nonprofits without at least a $10 \%$ decrease in net assets between 2006 and 2004 & $-17,335$ \\
Less observations before 2007 for net assets recovery sample & -2709 \\
Less observations after recovery & -1492 \\
Less observations with missing values & -373 \\
Final net assets sample size & 3348 \\
\hline
\end{tabular}

(Tuckman \& Chang, 1991). Nonprofits with a sufficient surplus can satisfy their financial needs and be more independent in making finance decisions; thus, they are less vulnerable to external uncertainty. Therefore, surplus (in 2004) is another indicator of pre-disaster financial resources.

\section{[IV] Revenue Diversification}

I use the Hirschman-Herfindahl index (HHI) to calculate revenue diversification. The $\mathrm{HHI}$ is widely used in nonprofit research (Carroll \& Stater, 2009; Hager, 2001; Prentice, 2016b; Tuckman \& Chang, 1991). It compares the ratios of the revenue generated from the three primary 
revenue sources (donative, commercial, and investment revenue) in the total revenue. Equation (3) shows how revenue diversification is calculated using the HHI, which ranges from zero-the revenue of a nonprofit is fully dependent on a single source-to one-the revenue is equally distributed among the three sources.

Revenue diversification(HHI)

$$
\begin{aligned}
& =\frac{1-\sum_{i=1}^{3}\left(\frac{\text { revenue source }_{i}}{\text { total revenue }^{2}}\right.}{2 / 3} ; i \\
& =\text { donative, commercial or investment }
\end{aligned}
$$

where $i$ denotes donative, commercial, or investment.

\section{[IV] Commercial Revenue}

This is the proportion of total revenue from commercial activities. It is coded as a binary variable following Carroll and Stater, (2009), with a value of one being assigned when more than $50 \%$ of the revenue is generated by commercial activities, and zero otherwise. This dummy measure indicates the primary fundraising structure of nonprofits. Nonprofits that rely on commercial revenue and those relying on donative revenue operate in different funding environments and have different revenue structures (Jegers $\&$ Verschueren, 2006). Donative revenue is more unpredictable than earned income (Froelich, 1999). Thus, nonprofits that rely on commercial revenue might be more stable in a disaster context.

[IV] Age

Age is calculated as the difference between the fiscal year and the year in which tax-exempt status was granted to a nonprofit.

\section{[IV] Size}

Organization size is indicated by the natural logarithm of the total assets of a nonprofit.

This study also included seven control variables. The subsector is the first control variable. Nonprofits from different subsectors in a disaster area compete for different pools of volunteers and donations (Carroll \& Stater, 2009), and subsectors with abundant resources are more likely to bounce back. The second control variable, "Severely Affected Areas," is coded as one if a nonprofit operates in the most severely affected counties, which are eligible for full individual and public assistance declared by FEMA. I also control for five variables at the county level to indicate nonprofit community characteristics, because community characteristics may make nonprofits operating in disasteraffected areas more vulnerable and less likely to recover to the pre-disaster level. Poverty rates and the percentage of the white population are added to the model to indicate community characteristics (Lam \& McDougle, 2016; Wu, 2021). The data for these two variables were obtained from the 2010 U.S. Census. The third control variable relating to community characteristics is density, which measures the number of nonprofits per 1000 people in a county (Paarlberg et al., 2018). Urban, indicating whether a nonprofit is located in urban areas (a county with 50,000 or more individuals, according to the Census Bureau's definition), was added as the fourth control regarding community characteristics and shows the ecological environment of nonprofits (Paarlberg et al., 2018). The Blau Index (BI) was added to the model to indicate the nonprofit market structure (Paarlberg et al., 2018). The BI formula is as follows:

$$
\begin{aligned}
\mathrm{BI} & =1-\sum\left({\text { organization share of non profitexpenditureincounty })^{2}}^{2}\right. \\
& =1-\sum\left(\frac{\text { expense }_{\mathrm{i}}}{\text { totalexpense }_{\mathrm{j}}}\right)^{2}
\end{aligned}
$$

where $i$ denotes nonprofits and $j$ denotes counties.

\section{Model Specification}

To explore the relationship between recovery and organizational financial capacities, a discrete-time hazard model was chosen. First, this model seeks to assess whether and when an event (recovery) occurs and can indicate the probability of recovery in a particular year (Singer \& Willett, 1993). Second, it can analyze all nonprofits-recovered or -unrecovered between 2007 and 2013.

To run the model, the original dataset must be organized into an organization-period dataset. Data for organization $i$ consist of $j$ rows, where $j$ represents the number of years for which data on organization $i$ is observed. The first row $(j=1)$ includes data points from 2006, which is the first year after Hurricane Katrina, and marks the start of the recovery period. Data are no longer included in the dataset once an organization has recovered from the disaster. As a result, the number of years $(j)$ for which an organization was observed varies. If an organization recovers in year $j$, the recovery cannot occur again before or after year $j$. Therefore, the model calculates the conditional probability of the recovery occurrence and is modeled as a logit function, as shown in Eq. (4).

$$
\ln \left(\frac{\left(\mathrm{t}_{\mathrm{ij}}\right)}{1-\left(\mathrm{t}_{\mathrm{ij}}\right)}\right)=\delta \mathrm{X}_{\mathrm{ij}}+\theta \mathrm{Z}_{\mathrm{i}}+\alpha \mathrm{D}_{\mathrm{j}}
$$

$\mathrm{X}$ represents the time-varying covariates for nonprofit $i$ in time period $j$, including revenue diversification, 
commercial revenue, age, and size. $Z$ represents time-invariant covariates, including equity ratio, surplus, subsector, poverty rate, percentage of white population, density, urban, and the BI. $D$ denotes the time structure of the hazard, which is a vector of period-specific intercepts.

\section{Results}

\section{Organizational Resilience in Terms of Total Expense Recovery}

The total expense recovery sample includes 686 organizations and 1,990 observations, and the descriptive statistics are shown in Tables 5 and 6 . Nearly $40 \%$ of nonprofits rely on commercial revenue. The average age of nonprofits in the sample is around 22 years, but a large standard deviation $(\sim 15$ years $)$ indicates that the age varies greatly.

Table 7 summarizes the distribution of the recovery rates of nonprofits, that is, a nonprofit's unadjusted likelihood of bouncing back to its pre-disaster total expense level (total expense in 2004) in a given period conditional on having the potential to recover at the beginning of that period. For example, in the "2007-2008" row of the table, of the 686 nonprofits in the sample at the beginning of the year 2007, 176 reached their original total expense level by the end of 2007.

The fifth column of the table shows the percentage of nonprofits that did not recover at the beginning of a period but recovered by its end. For example, row "2007-2008" indicates that $30.7 \%$ of the 686 nonprofits bounced back to their pre-disaster total expense level in this time period. The distribution of these recovery rates over time describes the baseline hazard function, which is used as the dependent variable in the discrete-time logit function. According to the last row, 167 nonprofits had the potential to recover in 2013-2014, and 11 of them actually recovered during this period. Therefore, 156 (167-11) nonprofits did not achieve recovery even 10 years after Hurricane Katrina. From a statistical perspective, the average recovery time of the sample cannot be calculated, because not all nonprofits recovered before 2013-2014. Instead, the median recovery time (or median lifetime) was calculated. The median lifetime "is the point in time by which we estimate that half of the sample has experienced the target event, half has not" (Singer \& Willett, 1993, p. 336). The median recovery time for nonprofits after Hurricane Katrina was three years. Figure 1 shows the number of nonprofits recovery events by years.

The variance inflation factor (VIF) of all variables in both the total expense and net assets samples were checked for multicollinearity issues. The VIF of all variables is less than 10 , indicating multicollinearity is not a problem ${ }^{2}$. Table 8 lists the results for the total expense recovery sample. Model 1 includes organization-level variables. Model 2 includes organization- and community-level variables. The results of the Bayesian information criterion are listed in the last row of the table and suggest that the performance of Model 2 is better than that of Model 1 . Thus, the following section focuses on interpreting the results of Model 2. Table 8 shows the coefficients and average marginal effects (AMEs) of the variables. The results are discussed in terms of AMEs because the interpretation of coefficients in log-odds is less intuitive. These results support Hypothesis 1, which proposes that nonprofits with more pre-disaster financial resources are more likely to bounce back after a disaster than nonprofits with less pre-disaster financial resources. Pre-disaster financial resources are represented by the equity ratio and surplus. The equity ratio is statistically significant at the 0.05 level. The AME of the equity ratio is 0.005 , that is, a one-unit increase in the equity ratio increases the probability that a nonprofit recovers its total expense by $0.5 \%$ on average. This finding suggests that nonprofits with higher equity ratios before the disaster are more likely to bounce back to their pre-disaster (i.e., 2004) total expense after a disaster. The surplus, the second indicator of pre-disaster financial resources, has a positive coefficient (0.827) and is statistically significant at the 0.001 level. Thus, nonprofits with more surpluses before the disaster are more likely to bounce back to their pre-disaster total expense after a disaster.

The results do not support Hypothesis 2a, which states that nonprofits with greater revenue diversification bounce back quicker than nonprofits with less revenue diversification. Diversifying revenue sources does not necessarily speed up total expense recovery. Hypothesis $2 b$ was also not supported. Nonprofits with more commercial revenue are less likely to recover. These findings suggest that the revenue structure of nonprofits does not have a direct influence on total expense recovery.

Hypothesis $3 \mathrm{a}$ was also not supported by the results. The effect of organizational age on total expense recovery was not statistically significant. By contrast, organizational size, measured as the natural log of total assets, positively affects total expense recovery at a 0.01 significance level. Thus, support is found for Hypothesis $3 \mathrm{~b}$, which expects larger nonprofits to have a higher chance of recovery.

For all the control variables, only food was statistically significant at the level of 0.05 . The AME of the variable

\footnotetext{
${ }^{2}$ Multicollinearity of the data is checked using Pearson correlation and the variance inflation factor (VIF) test. Both Pearson correlation and VIF test indicate that there is no major multicollinearity issue presented. For more information, see correlation tables and VIF test results in the Appendix.
} 
Table 5 Descriptive statistics of continuous variables for total expense recovery

\begin{tabular}{llrrll}
\hline & N & Mean & S.D & Min & Max \\
\hline Equity ratio & 1900 & 1.105 & 4.043 & -10.317 & 49.420 \\
Surplus & 1900 & -0.109 & 1.328 & -32.179 & 0.942 \\
Revenue & 1900 & 0.801 & 0.256 & 0.008 & 1 \\
$\quad$ diversification & & & & & \\
Age & 1900 & 22.660 & 15.399 & 1.92 & 72.97 \\
Size & 1900 & 12.653 & 2.232 & 0 & 20.391 \\
White & 1900 & 60.654 & 17.502 & 13.7 & 97.3 \\
Poverty & 1900 & 19.609 & 5.784 & 10.200 & 44.904 \\
Density & 1900 & 0.268 & 0.122 & 0.028 & 0.623 \\
Blau Index & 1900 & 0.668 & 0.218 & 0 & 0.926 \\
\hline
\end{tabular}

Table 6 Frequency table of categorical and dummy variables for total expense recovery

\begin{tabular}{lll}
\hline Expense recovery (DV) & Frequency & Percent \\
\hline 0 & 1829 & 83.98 \\
1 & 349 & 16.02 \\
Total & 2178 & 100.00 \\
Commercial revenue & & \\
0 & 1396 & 60.04 \\
1 & 929 & 39.96 \\
Total & 2325 & 100.00 \\
Severely affected area & & \\
0 & 1362 & 55.52 \\
1 & 1091 & 44.48 \\
Total & 2453 & 100.00 \\
Subsector & & \\
Health care & 470 & 19.16 \\
Mental health & 216 & 8.81 \\
Legal-related & 176 & 7.17 \\
Employment & 75 & 3.06 \\
Food & 41 & 1.67 \\
Housing & 303 & 12.35 \\
Disaster & 71 & 2.89 \\
Human services & 1101 & 44.88 \\
Total & 2453 & 100 \\
Urban & & \\
0 & 2406 & 100 \\
1 & & \\
Total & & \\
\hline & & \\
& &
\end{tabular}

"food" is 0.11 , which suggests that the likelihood of total expense recovery for a food nonprofit is 11 percentage points higher than that of a human service nonprofit.

\section{Organizational Resilience In Terms of Net Assets Recovery}

The net assets recovery sample includes 900 organizations and 3,348 observations. The descriptive statistics are shown in Tables 9 and 10. Similar to the total expense recovery sample, the average surplus of nonprofits in this sample is also negative (mean $=--.055$ ). Table 7 summarizes the distribution of recovery rates by period. The rates, often referred to as the hazard rate, describe a nonprofit's unadjusted likelihood of recovery in a given period conditional on having the potential to recover at the beginning of that period. The "2007-2008" row of Table 6 shows that, of the 900 nonprofits in the sample at the beginning of the year 2007, 144 regained their pre-disaster net assets level (i.e., 2004) by the end of 2007. Unlike the total expense recovery sample, the median net asset recovery time for this sample is longer, at approximately five years. Figure 2 shows the number of nonprofits recovery events by years.

Table 11 shows the time-discrete analysis results for the net asset-recovery sample. Hypothesis 1 has mixed supported when net assets are used as dependent variables. In contrast to total expense recovery, the pre-disaster equity of a nonprofit has no statistically significant relationship with total net asset recovery. However, similar to total expense recovery, the pre-disaster surplus is positive and statistically significant at the 0.05 level. Thus, pre-disaster surplus is helpful for total net asset recovery. Hypotheses $2 a$ and $2 b$ are not supported for the net asset-recovery sample. Commercial revenue has a negative coefficient and is statistically significant at the level of 0.05 . Thus, nonprofits with more commercial revenue are less likely to recover than nonprofits that rely on donations. Hypotheses $3 \mathrm{a}$ and $3 \mathrm{~b}$ are also rejected; the age and size of nonprofits are not associated with their recovery. Regarding control variables, only housing and density were statistically significant. The effect size of housing is -0.388 , which suggests that housing nonprofits are less likely to recover their net assets compared with human service nonprofits; density has a positive coefficient and is statistically significant at the 0.01 level, which suggests that nonprofits located in a community with several nonprofits are more likely to recover their net assets.

\section{Discussion}

The results show that the median post-disaster recovery time for nonprofits is between three and five years, and some nonprofits fail to reach their original performance level even by the end of 2013. It takes a long time for nonprofits to recover from a natural disaster, and some 
Table 7 Life tables for total expense and net assets recovery interval

\begin{tabular}{|c|c|c|c|c|c|c|c|c|}
\hline \multirow[t]{2}{*}{ Interval } & \multicolumn{4}{|c|}{ Total expense recovery } & \multicolumn{4}{|c|}{ Net assets recovery } \\
\hline & Beg. total & Recovered & Lost & Recovery rates & Beg. total & Recovered & Lost & Recovery rates \\
\hline $2007-2008$ & 686 & 176 & 50 & 0.307 & 900 & 144 & 45 & 0.179 \\
\hline 2008-2009 & 460 & 75 & 35 & 0.185 & 711 & 71 & 32 & 0.108 \\
\hline 2009-2010 & 350 & 47 & 36 & 0.152 & 608 & 58 & 39 & 0.104 \\
\hline 2010-2011 & 267 & 3 & 6 & 0.011 & 511 & 37 & 27 & 0.077 \\
\hline 2011-2012 & 258 & 26 & 33 & 0.114 & 447 & 24 & 30 & 0.057 \\
\hline $2012-2013$ & 199 & 11 & 21 & 0.060 & 393 & 19 & 25 & 0.051 \\
\hline 2013-2014 & 167 & 11 & 156 & 0.132 & 349 & 17 & 332 & 0.097 \\
\hline
\end{tabular}

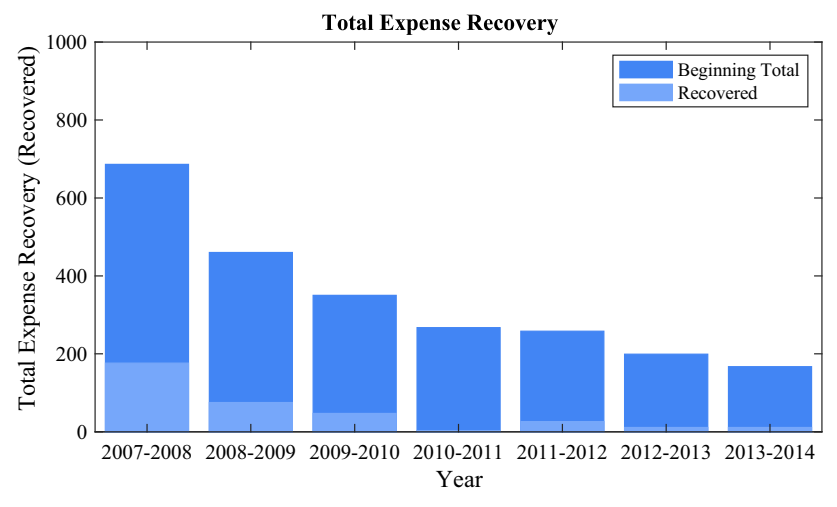

Fig. 1 Number of nonprofits total expense recoveries by year

nonprofits never have the opportunity to recover even after seven years.

Using total expense as an indicator, the results reveal that pre-disaster equity is positively associated with organizational resilience. Nonprofits with a higher equity ratio, who can convert their equity to cash for spending on disaster relief or programs, are more financially resilient. By contrast, the results of net asset recovery show that the equity ratio may not help nonprofits to recover their net assets. There are two possible reasons for this divergence. First, most nonprofits do not have a large number of funds that can be spent simultaneously on their services and property repairs. They may prioritize maintaining operations and programs (total expense recovery) over repairing or building their lost properties (net assets recovery).

Second, a large portion of nonprofit equity is restricted equity, meant for use in programmatic spending. Therefore, higher equity may not be able to help with net asset recovery the way it helps with total expense recovery. Additionally, this study revealed a statistically significant relationship between pre-disaster surplus (in 2004) and organizational resilience in terms of total expenses and net assets. This result is consistent with the literature-organizations with more cash can better cope with external risks as they can afford to spend on operations and programs immediately.

The time-discrete hazard model suggests that diversifying revenue portfolios does not help with organizational resilience either in terms of total expense or net asset recovery. Studies have yielded complex results for revenue diversification. Some claim that revenue diversification makes nonprofits more flexible in their finances and, therefore, can reduce their vulnerability to internal and external uncertainties (Carroll \& Stater, 2009; Froelich, 1999). Others claim that revenue concentration increases nonprofit efficiency by decreasing administrative costs and fundraising expenses (Frumkin \& Keating, 2011; Wicker \& Breuer, 2013). More recent studies find that selecting nonprofit revenue portfolios is more complex than simply adding different types of revenue sources, and revenue portfolios should be chosen based on the specific conditions of the organizations, such as the nature of their services (Hung \& Hager, 2019; Prentice, 2016b; Qu, 2019; Young, 2007).

Nonprofits that depend on commercial revenue recover slower than nonprofits that rely on other types of revenues in terms of net asset recovery. This finding is inconsistent with the literature, which finds that commercial revenues are associated with low levels of insolvency risk, funding disruption risk, and program disruption risk (Keating et al., 2005); less revenue volatility (Carroll \& Stater, 2009); faster growth in revenue (Frumkin \& Keating, 2011); and higher resiliency during economic downturns (Joseph, 2011; Salamon, Geller, \& Spence, 2009). Possibly, commercial revenue is more stable than other revenue sources, such as donative revenues, which are more unpredictable and are more likely to change in different settings (Froelich, 1999). For example, private donations can drop greatly when economic conditions are poor (Joseph, 2011; Salamon, Geller, \& Spence, 2009). However, Prentice, (2016b) finds that commercial revenue is not clearly related to financial health. Therefore, commercial revenue may 
Table 8 Results for nested discrete-time hazard model of total expense recovery

\begin{tabular}{|c|c|c|c|c|}
\hline \multirow[t]{2}{*}{ Variables } & \multicolumn{2}{|l|}{ Model 1} & \multicolumn{2}{|l|}{ Model 2} \\
\hline & Coefficient & AME & Coefficient & AME \\
\hline \multirow[t]{2}{*}{ Equity ratio } & $0.035^{*}$ & $0.005^{*}$ & $0.035^{*}$ & $0.005^{*}$ \\
\hline & $(0.016)$ & $(0.002)$ & $(0.017)$ & $(0.002)$ \\
\hline \multirow[t]{2}{*}{ Surplus } & $0.827 * * *$ & $0.109 * * *$ & $0.831 * * *$ & $0.110 * * *$ \\
\hline & $(0.245)$ & $(0.032)$ & $(0.245)$ & $(0.032)$ \\
\hline \multirow{2}{*}{$\begin{array}{l}\text { Revenue } \\
\text { diversification }\end{array}$} & -0.228 & -0.030 & -0.218 & -0.029 \\
\hline & $(0.249)$ & $(0.033)$ & $(0.250)$ & $(0.033)$ \\
\hline \multirow[t]{2}{*}{ Commercial revenue } & -0.189 & -0.025 & -0.185 & -0.024 \\
\hline & $(0.137)$ & $(0.018)$ & $(0.138)$ & $(0.018)$ \\
\hline \multirow[t]{2}{*}{ Age } & -0.003 & -0.000 & -0.003 & -0.000 \\
\hline & $(0.005)$ & $(0.000)$ & $(0.005)$ & $(0.000)$ \\
\hline \multirow[t]{2}{*}{ Size } & $0.098 * *$ & $0.013 * *$ & $0.097 * *$ & $0.013 * * *$ \\
\hline & $(0.034)$ & $(0.004)$ & $(0.034)$ & $(0.004)$ \\
\hline \multirow[t]{2}{*}{ Severely affected area } & -0.067 & -0.009 & -0.072 & -0.010 \\
\hline & $(0.130)$ & $(0.017)$ & $(0.140)$ & $(0.019)$ \\
\hline \multirow[t]{2}{*}{ Disaster } & 0.610 & 0.081 & 0.619 & 0.082 \\
\hline & $(0.353)$ & $(0.047)$ & $(0.354)$ & $(0.047)$ \\
\hline \multirow[t]{2}{*}{ Health care } & 0.128 & 0.017 & 0.122 & 0.015 \\
\hline & $(0.176)$ & $(0.023)$ & $(0.177)$ & $(0.023)$ \\
\hline \multirow[t]{2}{*}{ Mental health } & 0.012 & 0.002 & 0.015 & 0.002 \\
\hline & $(0.240)$ & $(0.032)$ & $(0.241)$ & $(0.032)$ \\
\hline \multirow[t]{2}{*}{ Legal-related } & 0.115 & 0.015 & 0.126 & 0.017 \\
\hline & $(0.260)$ & $(0.034)$ & $(0.261)$ & $(0.035)$ \\
\hline \multirow[t]{2}{*}{ Employment } & -0.194 & -0.028 & -0.221 & -0.029 \\
\hline & $(0.403)$ & $(0.054)$ & $(0.406)$ & $(0.054)$ \\
\hline \multirow[t]{2}{*}{ Food } & $0.829 *$ & $0.110^{*}$ & $0.844 *$ & $0.112 *$ \\
\hline & $(0.417)$ & $(0.055)$ & $(0.419)$ & $(0.055)$ \\
\hline \multirow[t]{2}{*}{ Housing } & 0.0214 & 0.003 & 0.019 & 0.002 \\
\hline & $(0.208)$ & $(0.028)$ & $(0.210)$ & $(0.028)$ \\
\hline \multirow[t]{2}{*}{ White } & & & 0.001 & 0.000 \\
\hline & & & $(0.006)$ & $(0.001)$ \\
\hline \multirow[t]{2}{*}{ Poverty } & & & 0.005 & 0.001 \\
\hline & & & $(0.020)$ & $(0.003)$ \\
\hline \multirow[t]{2}{*}{ Density } & & & 0.195 & 0.026 \\
\hline & & & $(0.682)$ & $(0.090)$ \\
\hline \multirow[t]{2}{*}{ Urban } & & & 0.081 & 0.011 \\
\hline & & & $(0.230)$ & $(0.030)$ \\
\hline \multirow[t]{2}{*}{ Blau Index } & & & -0.221 & -0.029 \\
\hline & & & $(0.345)$ & $(0.046)$ \\
\hline \multirow[t]{2}{*}{2008} & $-0.571 * * *$ & $-0.089 * * *$ & $-0.570 * * *$ & $-0.089 * * *$ \\
\hline & $(0.157)$ & $(0.023)$ & $(0.157)$ & $(0.024)$ \\
\hline 2009 & $-0.798 * * *$ & $-0.116^{* * *}$ & $-0.794 * * *$ & $-0.116 * * *$ \\
\hline & $(0.187)$ & $(0.025)$ & $(0.187)$ & $(0.025)$ \\
\hline 2010 & -0.808 & -0.117 & -0.786 & -0.114 \\
\hline & $(0.783)$ & $(0.088)$ & $(0.784)$ & $(0.090)$ \\
\hline 2011 & $-1.004 * * *$ & $-0.137 * * *$ & $-0.991 * *$ & -0.137 \\
\hline & $(0.301)$ & $(0.032)$ & $(0.302)$ & $(0.032)$ \\
\hline
\end{tabular}


Table 8 continued

\begin{tabular}{|c|c|c|c|c|}
\hline \multirow[t]{2}{*}{ Variables } & \multicolumn{2}{|l|}{ Model 1} & \multicolumn{2}{|l|}{ Model 2} \\
\hline & Coefficient & AME & Coefficient & AME \\
\hline 2012 & $\begin{array}{l}-1.546 * * * \\
(0.360)\end{array}$ & $\begin{array}{l}-0.180 * * * \\
(0.027)\end{array}$ & $\begin{array}{l}-1.533^{\text {*** }} \\
(0.361)\end{array}$ & $\begin{array}{l}-0.179 * * * \\
(0.027)\end{array}$ \\
\hline 2013 & $\begin{array}{l}-1.866^{* * * *} \\
(0.432)\end{array}$ & $\begin{array}{l}-0.197 * * * \\
(0.026)\end{array}$ & $\begin{array}{l}-1.855^{* * *} \\
(0.433)\end{array}$ & $\begin{array}{l}-0.197 * * * \\
(0.025)\end{array}$ \\
\hline Intercept & $\begin{array}{l}-2.067 * * * \\
(0.471)\end{array}$ & & $\begin{array}{l}-2.212^{*} \\
(0.970)\end{array}$ & \\
\hline$N$ (observations) & 1900 & & 1900 & \\
\hline$N$ (nonprofits) & $686-$ & & $686-$ & \\
\hline $\mathrm{BIC}$ & $12,553.325$ & & $12,518.362$ & \\
\hline
\end{tabular}

$* p<0.05, * * p<0.01, * * * p<0.001$

Table 9 Descriptive table for net assets recovery

\begin{tabular}{llrrll}
\hline & $\mathrm{N}$ & Mean & S.D & Min & Max \\
\hline Equity ratio & 3348 & 1.590 & 5.226 & -48.189 & 33.033 \\
Surplus & 3348 & -0.055 & 0.370 & -4.969 & 1 \\
Revenue & 3348 & 0.811 & 0.262 & 0.008 & 1 \\
$\quad$ diversification & & & & & \\
Age & 3348 & 21.049 & 14.576 & 1.95 & 72.97 \\
Size & 3348 & 12.642 & 2.327 & 0 & 20.537 \\
White & 3348 & 61.739 & 15.746 & 15 & 97.3 \\
Poverty & 3348 & 19.132 & 5.867 & 10.200 & 44.904 \\
Density & 3348 & 0.254 & 0.119 & 0.029 & 0.623 \\
Blau Index & 3348 & 0.704 & 0.236 & 0 & 1 \\
\hline
\end{tabular}

contribute to nonprofit financial health differently when using different financial measures and in different settings. The natural disaster context might be a special case, since private donations and government support to nonprofits increase after natural disasters. Nonprofits that rely on donations are more familiar with donor relations, so they can leverage those relationships and adaptively implement donor appeals following a disaster. In conclusion, nonprofits need to be extremely cautious when considering transferring revenue strategies, such as diversifying revenue streams or increasing commercial revenue, which are useful in normal non-disaster conditions, but may not help in a disaster recovery context.

Further, based on the total expense recovery sample, larger nonprofits bounced back quicker than smaller ones, consistent with the expectation that larger nonprofits have more resources to cope with adverse conditions. Nonprofit financial recovery is associated with subsectors. Food nonprofits, as opposed to human services nonprofits, are especially likely to see recovery in their total expense,
Table 10 Frequency table of categorical and dummy variables for net assets recovery

\begin{tabular}{llr}
\hline Net assets recovery (DV) & Frequency & Percent \\
\hline 0 & 3351 & 90.06 \\
1 & 370 & 9.94 \\
Total & 3721 & 100.00 \\
Commercial revenue & & \\
0 & 1837 & 51.57 \\
1 & 1725 & 48.43 \\
Total & 3562 & 100.00 \\
Severely affected area & & \\
0 & 2431 & 65.33 \\
1 & 1290 & 34.67 \\
Total & 3721 & 100.00 \\
Subsector & & \\
Health care & 635 & 17.07 \\
Mental health & 309 & 8.30 \\
Legal-related & 208 & 5.59 \\
Employment & 116 & 3.12 \\
Food & 60 & 1.61 \\
Housing & 651 & 17.50 \\
Disaster & 97 & 2.61 \\
Human services & 1645 & 100.00 \\
Total & 3721 & \\
Urban & & \\
0 & 3107 & \\
1 & & \\
Total & & \\
\hline & & \\
& &
\end{tabular}

while housing nonprofits, again compared to human service nonprofits, are less likely to see recovery in their net assets. Regarding community characteristics, the density of nonprofits in a county is positively associated with net asset 


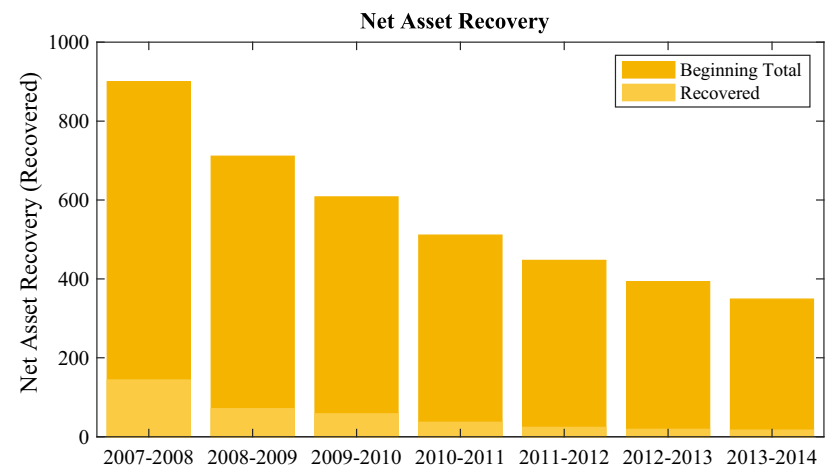

Fig. 2 Number of nonprofits net assets recoveries by year

recovery. This may be because high nonprofit density increases public awareness of the sector and more supportive networks might exist for nonprofits (McDougle \& Lam, 2014); thus, nonprofits in communities with high nonprofit density can access resources for disaster recovery.

Finally, this study contributes to both research and practice. First, I extend the concept of organizational resilience to the nonprofit sector. I also enrich the financial management literature on nonprofits, since most literature examines nonprofit vulnerability rather than resilience. I find that organizational characteristics such as revenue diversification and commercial revenue, which alleviate financial vulnerability, do not directly translate to high financial resilience. Indeed, commercial revenue hinders nonprofits' ability to recover from natural disasters.

This study provides several insights for practitioners. First, it may take years for nonprofits to recover from a significant disaster, so nonprofit managers should consider long-term recovery plans, and nonprofit funders should consider offering long-term support.

Second, a higher equity ratio helps nonprofits achieve total expense recovery. This means that nonprofit funders and policymakers should consider giving nonprofits more flexibility in building unrestricted equity instead of forcing them to spend only on specific programs, especially during the disaster recovery period.

Third, nonprofits with more surplus are more likely to recover their total expenses. Thus, nonprofit managers should consider reserving funds to cope with external risks.

Fourth, nonprofit managers should realize that the revenue strategies that help nonprofits reduce vulnerability (such as diversifying revenue sources and relying on commercial revenue) may not help nonprofit recovery from natural disasters. Nonprofits relying on diverse revenue sources and commercial revenue may consider restructuring the revenue portfolio by concentrating on one or two revenue sources and reducing dependency on commercial revenue when they are affected by disasters.

Finally, it is more difficult for small nonprofits to bounce back to their original performance level. Managers from small nonprofits need to realize this and react accordingly. In addition, funders, donors, policymakers, and other external stakeholders should also be aware of and provide more resources such as grants, volunteer hours, and information to small nonprofits.

\section{Limitations}

This study has several limitations. First, one needs to be cautious when generalizing the findings to other disasters because each disaster has its unique characteristics and is different in magnitude.

Second, there is a sampling bias in the NCCS Core PC data files. This sample did not include small nonprofits (with annual revenue less than $\$ 25,000$ ), as they are not required to file the Internal Revenue Service Form 990. Extra caution must be exercised when generalizing the findings to small nonprofits.

Third, this analysis has a survival bias. The sample only includes nonprofits that filed their tax returns from 2001 to 2014. Nonprofits that did not survive during this period were not included in this sample.

Fourth, the study uses 2004 as the baseline to assess the recovery of nonprofits; however, the service demands of nonprofits are changing over time. Hence, the 2004 baseline for total expense might not necessarily be an accurate proxy of needs at a later time.

Fifth, unrestricted assets are more likely to decrease when nonprofits are affected by natural disasters because unrestricted net assets are closer to the actual amount of equity that nonprofits can easily liquidate and spend to reduce financial distress (Calabrese, 2011). Unrestricted net asset properties, such as real estate, might also be affected by natural disasters. However, such assets and properties are not listed as an independent category in the core files. Unrestricted net assets and restricted net assets are combined and reported as total net assets in the core files. Therefore, I can only use net asset recovery to proxy for unrestricted assets and properties such as real estate, which might not be accurate.

Finally, the retrieved sample consists of data up to the year 2013. Some nonprofits, however, failed to recover even eight years after Hurricane Katrina. Thus, this article lost the track of nonprofit recovery after 2014. 
Table 11 Results for nested discrete-time hazard model of net assets recovery

\begin{tabular}{|c|c|c|c|c|}
\hline \multirow[t]{2}{*}{ Variables } & \multicolumn{2}{|l|}{ Model 3} & \multicolumn{2}{|l|}{ Model 4} \\
\hline & Coefficient & AME & Coefficient & AME \\
\hline \multirow[t]{2}{*}{ Equity ratio } & -0.015 & -0.001 & -0.014 & -0.001 \\
\hline & $(0.013)$ & $(0.001)$ & $(0.013)$ & $(0.001)$ \\
\hline \multirow[t]{2}{*}{ Surplus } & $0.408^{*}$ & $0.037 *$ & $0.409 *$ & $0.037 *$ \\
\hline & $(0.207)$ & $(0.019)$ & $(0.205)$ & $(0.018)$ \\
\hline \multirow{2}{*}{$\begin{array}{l}\text { Revenue } \\
\text { diversification }\end{array}$} & -0.404 & -0.036 & -0.418 & -0.038 \\
\hline & $(0.218)$ & $(0.020)$ & $(0.219)$ & $(0.020)$ \\
\hline \multirow[t]{2}{*}{ Commercial revenue } & $-0.366^{* *}$ & $-0.033 * *$ & $-0.385^{* *}$ & $-0.035 * *$ \\
\hline & $(0.124)$ & $(0.011)$ & $(0.125)$ & $(0.011)$ \\
\hline \multirow[t]{2}{*}{ Age } & -0.000 & -0.000 & -0.001 & -0.000 \\
\hline & $(0.005)$ & $(0.000)$ & $(0.005)$ & $(0.000)$ \\
\hline \multirow[t]{2}{*}{ Size } & -0.018 & -0.0016 & -0.022 & -0.002 \\
\hline & $(0.029)$ & $(0.002)$ & $(0.029)$ & $(0.003)$ \\
\hline \multirow[t]{2}{*}{ Severely affected area } & -0.088 & -0.008 & -0.216 & -0.019 \\
\hline & $(0.123)$ & $(0.011)$ & $(0.135)$ & $(0.012)$ \\
\hline \multirow[t]{2}{*}{ Disaster } & 0.201 & 0.018 & 0.206 & 0.018 \\
\hline & $(0.331)$ & $(0.030)$ & $(0.332)$ & $(0.030)$ \\
\hline \multirow[t]{2}{*}{ Health care } & 0.058 & 0.005 & 0.053 & 0.005 \\
\hline & $(0.167)$ & $(0.015)$ & $(0.169)$ & $(0.015)$ \\
\hline \multirow[t]{2}{*}{ Mental health } & -0.049 & -0.004 & -0.107 & -0.010 \\
\hline & $(0.220)$ & $(0.020)$ & $(0.222)$ & $(0.020)$ \\
\hline \multirow[t]{2}{*}{ Legal-related } & 0.041 & 0.004 & 0.007 & 0.001 \\
\hline & $(0.247)$ & $(0.022)$ & $(0.248)$ & $(0.022)$ \\
\hline \multirow[t]{2}{*}{ Employment } & -0.179 & -0.016 & -0.149 & -0.013 \\
\hline & $(0.347)$ & $(0.031)$ & $(0.350)$ & $(0.031)$ \\
\hline \multirow[t]{2}{*}{ Food } & 0.139 & 0.012 & 0.106 & 0.020 \\
\hline & $(0.398)$ & $(0.036)$ & $(0.399)$ & $(0.036)$ \\
\hline \multirow[t]{2}{*}{ Housing } & -0.365 & -0.033 & $-0.388^{*}$ & $-0.035^{*}$ \\
\hline & $(0.197)$ & $(0.018)$ & $(0.197)$ & $(0.018)$ \\
\hline \multirow[t]{2}{*}{ White } & & & -0.002 & -0.000 \\
\hline & & & $(0.006)$ & $(0.001)$ \\
\hline \multirow[t]{2}{*}{ Poverty } & & & -0.004 & -0.000 \\
\hline & & & $(0.018)$ & $(0.002)$ \\
\hline \multirow[t]{2}{*}{ Density } & & & $1.483 * *$ & $0.133 * *$ \\
\hline & & & $(0.530)$ & $(0.048)$ \\
\hline \multirow[t]{2}{*}{ Urban } & & & 0.156 & 0.014 \\
\hline & & & $(0.204)$ & $(0.018)$ \\
\hline \multirow[t]{2}{*}{ Blau Index } & & & -0.128 & -0.012 \\
\hline & & & $(0.346)$ & $(0.031)$ \\
\hline \multirow[t]{2}{*}{2008} & $-0.481 * *$ & $\begin{array}{c}-0.055 \\
* * *\end{array}$ & $-0.452 * *$ & $-0.050 * *$ \\
\hline & $(0.157)$ & $(0.017)$ & $(0.158)$ & $(0.017)$ \\
\hline 2009 & $-0.520 * *$ & $-0.058 * * *$ & & $-0.054 * *$ \\
\hline & $(0.168)$ & $(0.018)$ & $-0.489 * *$ & $(0.018)$ \\
\hline 2010 & $-0.815^{* * *}$ & -0.083 & $(0.169)$ & $-0.073 * * *$ \\
\hline & $(0.196)$ & $(0.018)$ & $-0.720 * *$ & $(0.021)$ \\
\hline 2011 & $-1.268 * * *$ & $\begin{array}{c}-0.110 \\
* * *\end{array}$ & $(0.232)$ & $-0.103 * * *$ \\
\hline & $(0.302)$ & $(0.019)$ & $-1.211^{* * *}$ & $(0.019)$ \\
\hline
\end{tabular}


Table 11 continued

\begin{tabular}{|c|c|c|c|c|}
\hline \multirow[t]{2}{*}{ Variables } & \multicolumn{2}{|l|}{ Model 3} & \multicolumn{2}{|l|}{ Model 4} \\
\hline & Coefficient & AME & Coefficient & AME \\
\hline \multirow[t]{2}{*}{2012} & $-1.149 * * *$ & $-0.104 * * *$ & $(0.303)$ & $-0.097 * * *$ \\
\hline & $(0.277)$ & (0.019) & $-1.089 * * *$ & $(0.019)$ \\
\hline \multirow[t]{2}{*}{2013} & $-1.516^{* * *}$ & $-0.121 * * *$ & $(0.277)$ & $-0.114 * * *$ \\
\hline & $(0.325)$ & $(0.018)$ & $-1.443 * * *$ & $(0.018)$ \\
\hline \multirow[t]{2}{*}{ Intercept } & $-0.820^{*}$ & & $(0.326)$ & \\
\hline & $(0.383)$ & & -0.930 & \\
\hline$N$ (observations) & 3348 & & 3348 & \\
\hline$N$ (nonprofits) & 900 & & 900 & \\
\hline $\mathrm{BIC}$ & $-24,859.961$ & & $-24,830.484$ & \\
\hline
\end{tabular}

\section{Appendix}

See Table 12, 13, 14, and 15.

Table 12 Correlation Table for Total Expense Sample

\begin{tabular}{|c|c|c|c|c|c|c|c|c|c|c|c|}
\hline Variables & 1 & 2 & 3 & 4 & 5 & 6 & 7 & 8 & 9 & 10 & 11 \\
\hline 1. Expense recover & 1.0000 & & & & & & & & & & \\
\hline 2. Equity ratio & 0.0508 & 1.0000 & & & & & & & & & \\
\hline 3. Surplus & 0.0376 & -0.6060 & 1.0000 & & & & & & & & \\
\hline 4. Revenue diversification & -0.0470 & -0.0018 & -0.0471 & 1.0000 & & & & & & & \\
\hline 5. Commercial revenue & -0.0372 & -0.1477 & 0.0253 & -0.0708 & 1.0000 & & & & & & \\
\hline 6. Age & -0.0267 & 0.0401 & -0.0087 & -0.2007 & 0.0351 & 1.0000 & & & & & \\
\hline 7. Size & 0.0623 & 0.1673 & -0.0871 & -0.1704 & 0.1367 & 0.3409 & 1.0000 & & & & \\
\hline 8. Affected area & -0.0121 & -0.0148 & 0.0636 & -0.0105 & 0.0248 & 0.1229 & 0.0607 & 1.0000 & & & \\
\hline 9. Disaster & 0.0426 & 0.0616 & -0.0278 & -0.0223 & 0.0130 & -0.0817 & -0.0378 & -0.0077 & 1.0000 & & \\
\hline 10. Health care & 0.0218 & 0.1542 & -0.1035 & -0.1122 & 0.0201 & 0.2164 & 0.1836 & -0.0147 & -0.0841 & 1.0000 & \\
\hline 11. Mental health & -0.0071 & -0.0216 & 0.0109 & -0.0113 & -0.0238 & 0.0179 & -0.0122 & -0.0060 & -0.0536 & -0.1513 & 1.0000 \\
\hline 12. Legal-related & -0.0089 & -0.0283 & 0.0153 & 0.0558 & -0.1075 & 0.0040 & -0.0867 & -0.0231 & -0.0480 & -0.1354 & -0.0864 \\
\hline 13. Employment & -0.0031 & -0.0113 & 0.0150 & 0.0704 & -0.0172 & -0.0505 & 0.0147 & 0.0221 & -0.0307 & -0.0865 & -0.0552 \\
\hline 14. Food & 0.0415 & -0.0209 & -0.0068 & 0.0394 & -0.0426 & -0.0684 & -0.1039 & 0.0177 & -0.0225 & -0.0635 & -0.0405 \\
\hline 15. Housing & 0.0066 & -0.0655 & 0.0288 & -0.0132 & 0.1466 & 0.0432 & 0.2306 & 0.0629 & -0.0648 & -0.1828 & -0.1167 \\
\hline 16. Human service & -0.0370 & -0.0631 & 0.0546 & 0.0468 & -0.0303 & -0.1495 & -0.2131 & -0.0242 & -0.1558 & -0.4393 & -0.2804 \\
\hline 17. White & 0.0094 & 0.0363 & 0.0047 & 0.0935 & 0.0170 & -0.1789 & -0.1135 & -0.3175 & 0.0569 & -0.0077 & 0.0263 \\
\hline 18. Poverty & 0.0043 & -0.0211 & 0.0319 & -0.0879 & -0.0885 & 0.1685 & 0.0766 & 0.1404 & -0.0126 & 0.0065 & -0.0746 \\
\hline 19. Density & 0.0151 & -0.0037 & -0.0040 & -0.0363 & -0.0040 & 0.1371 & 0.0983 & 0.2871 & -0.0164 & 0.0106 & -0.0272 \\
\hline 20. Urban & 0.0043 & 0.0108 & -0.0318 & 0.0129 & 0.1229 & 0.0555 & 0.1071 & 0.1867 & -0.0137 & -0.0194 & 0.0725 \\
\hline 21. Blau Index & -0.0030 & -0.0082 & -0.0324 & 0.0204 & 0.0484 & 0.1097 & 0.0977 & 0.1349 & -0.0052 & -0.0407 & 0.0414 \\
\hline 22. Year & -0.1710 & -0.0293 & -0.0166 & 0.0542 & 0.0163 & 0.1753 & 0.0504 & 0.0205 & -0.0132 & 0.0027 & 0.0206 \\
\hline Variables & 12 & 13 & 14 & 15 & 16 & 17 & 18 & 19 & 20 & 21 & 22 \\
\hline \multicolumn{12}{|l|}{ 1. Expense recovery } \\
\hline \multicolumn{12}{|l|}{ 2. Equity ratio } \\
\hline \multicolumn{12}{|l|}{ 3. Surplus } \\
\hline 4. Revenue diversific & & & & & & & & & & & \\
\hline
\end{tabular}


Table 12 continued

\begin{tabular}{|c|c|c|c|c|c|c|c|c|c|c|c|}
\hline Variables & 12 & 13 & 14 & 15 & 16 & 17 & 18 & 19 & 20 & 21 & 22 \\
\hline \multicolumn{12}{|c|}{ 5. Commercial revenue } \\
\hline \multicolumn{12}{|l|}{ 6. Age } \\
\hline \multicolumn{12}{|l|}{ 7. Size } \\
\hline \multicolumn{12}{|l|}{ 8. Affected area } \\
\hline \multicolumn{12}{|l|}{ 9. Disaster } \\
\hline \multicolumn{12}{|l|}{ 10. Health care } \\
\hline \multicolumn{12}{|l|}{ 11. Mental health } \\
\hline 12. Legal-related & 1.0000 & & & & & & & & & & \\
\hline 13. Employment & -0.0494 & 1.0000 & & & & & & & & & \\
\hline 14. Food & -0.0362 & -0.0232 & 1.0000 & & & & & & & & \\
\hline 15. Housing & -0.1044 & -0.0667 & -0.0489 & 1.0000 & & & & & & & \\
\hline 16. Human service & -0.2509 & -0.1603 & -0.1177 & -0.3388 & 1.0000 & & & & & & \\
\hline 17. White & 0.0388 & -0.0616 & 0.0371 & -0.0792 & 0.0159 & 1.0000 & & & & & \\
\hline 18. Poverty & 0.0111 & 0.0770 & -0.0286 & 0.0763 & -0.0339 & -0.7352 & 1.0000 & & & & \\
\hline 19. Density & -0.0171 & 0.0366 & -0.0387 & 0.0902 & -0.0409 & -0.6006 & 0.4997 & 1.0000 & & & \\
\hline 20. Urban & 0.0086 & 0.0449 & 0.0347 & 0.0706 & -0.0970 & 0.0010 & -0.3038 & 0.1410 & 1.0000 & & \\
\hline 21. Blau Index & 0.0500 & -0.0061 & 0.0349 & 0.0805 & -0.0757 & -0.1965 & -0.0321 & 0.2440 & 0.3356 & 1.0000 & \\
\hline 22. Year & 0.0287 & 0.0007 & -0.0270 & 0.0005 & -0.0179 & -0.0150 & 0.0189 & -0.0871 & 0.0234 & 0.0947 & 1.0000 \\
\hline
\end{tabular}


Table 13 Correlation table for net assets sample

\begin{tabular}{|c|c|c|c|c|c|c|c|c|c|c|c|}
\hline Variables & 1 & 2 & 3 & 4 & 5 & 6 & 7 & 8 & 9 & 10 & 11 \\
\hline 1. Expense recovery & 1.0000 & & & & & & & & & & \\
\hline 2. Equity ratio & -0.0444 & 1.0000 & & & & & & & & & \\
\hline 3. Surplus & 0.0507 & -0.3393 & 1.0000 & & & & & & & & \\
\hline 4. Revenue diversification & -0.0363 & 0.0442 & -0.0154 & 1.0000 & & & & & & & \\
\hline 5. Commercial revenue & -0.0694 & 0.0751 & -0.0956 & 0.0052 & 1.0000 & & & & & & \\
\hline 6. Age & -0.0192 & 0.0370 & -0.0514 & -0.1464 & 0.0002 & 1.0000 & & & & & \\
\hline 7. Size & -0.0459 & 0.1339 & -0.0604 & -0.0741 & 0.2256 & 0.3419 & 1.0000 & & & & \\
\hline 8. Affected area & -0.0137 & -0.0271 & -0.0337 & 0.0096 & -0.0368 & 0.0526 & -0.0693 & 1.0000 & & & \\
\hline 9. Disaster & 0.0133 & 0.0328 & 0.0881 & -0.0081 & -0.0035 & -0.0501 & -0.0641 & 0.0332 & 1.0000 & & \\
\hline 10. Health care & 0.0116 & -0.0177 & -0.1173 & -0.0497 & 0.0722 & 0.1875 & 0.1822 & 0.0493 & -0.0742 & 1.0000 & \\
\hline 11. Mental health & -0.0024 & -0.0610 & 0.0501 & -0.0326 & -0.0099 & -0.0204 & -0.0523 & 0.0141 & -0.0492 & -0.1365 & 1.0000 \\
\hline 12. Legal-related & 0.0091 & -0.0333 & 0.0449 & 0.0731 & -0.1347 & -0.0108 & -0.0928 & -0.0298 & -0.0398 & -0.1104 & -0.0732 \\
\hline 13. Employment & 0.0024 & -0.0470 & 0.0201 & 0.0685 & -0.0613 & -0.0432 & -0.0250 & -0.0494 & -0.0293 & -0.0814 & -0.0540 \\
\hline 14. Food & 0.0145 & 0.0175 & 0.0049 & 0.0121 & -0.1038 & -0.0279 & -0.0488 & -0.0126 & -0.0209 & -0.0581 & -0.0385 \\
\hline 15. Housing & -0.0585 & 0.1979 & -0.1092 & 0.0003 & 0.2324 & -0.0518 & 0.2718 & -0.0575 & -0.0753 & -0.2089 & -0.1386 \\
\hline 16. Human service & 0.0243 & -0.0872 & 0.0872 & -0.0039 & -0.1162 & -0.0478 & -0.2334 & 0.0224 & -0.1456 & -0.4038 & -0.2679 \\
\hline 17. White & -0.0093 & 0.0201 & 0.0721 & 0.0522 & 0.0171 & -0.1268 & -0.0292 & -0.2405 & 0.0391 & -0.0171 & 0.0259 \\
\hline 18. Poverty & 0.0134 & -0.0480 & 0.0163 & -0.0440 & -0.0959 & 0.0726 & -0.0346 & 0.0811 & -0.0409 & 0.0518 & -0.0585 \\
\hline 19. Density & 0.0553 & -0.0671 & -0.0020 & -0.0137 & -0.0054 & 0.0493 & 0.0151 & 0.2268 & -0.0157 & 0.0536 & 0.0406 \\
\hline 20. Urban & 0.0074 & 0.0070 & -0.0381 & 0.0017 & 0.0714 & 0.0488 & 0.0634 & 0.1382 & -0.0091 & -0.0813 & 0.0839 \\
\hline 21. Blau Index & -0.0186 & 0.0605 & -0.0440 & -0.0017 & 0.0499 & 0.1049 & 0.0697 & 0.0433 & -0.0276 & -0.0861 & 0.0651 \\
\hline 22. Year & -0.1342 & 0.0507 & -0.0336 & 0.0199 & 0.0333 & 0.1739 & 0.0692 & 0.0010 & 0.0061 & -0.0267 & 0.0212 \\
\hline Variables & 12 & 13 & 14 & 15 & 16 & 17 & 18 & 19 & 20 & 21 & 22 \\
\hline
\end{tabular}

1. Expense recovery

2. Equity ratio

3. Surplus

4. Revenue diversification

5. Commercial revenue

6. Age

7. Size

8. Affected area

9. Disaster

10. Health care

11. Mental health

12. Legal-related

13. Employment

14. Food

15. Housing

16. Human service

17. White

18. Poverty

19. Density

20. Urban

21. Blau Index

22. Year
1.0000

$-0.0436 \quad 1.0000$

$\begin{array}{lll}-0.0312 & -0.0230 & 1.0000\end{array}$

$\begin{array}{llll}-0.1121 & -0.0826 & -0.0590 & 1.0000\end{array}$

$-0.2166-0.1597$

0.0431

0.0017

0.0052

0.0451

0.0153

0.0134 $\begin{array}{lll}-0.1140 & -0.4099 & 1.0000 \\ 0.0242 & -0.0032 & -0.0552\end{array}$

$\begin{array}{lll}-0.0036 & -0.0282 & 0.0273\end{array}$

$\begin{array}{lll}0.0066 & -0.0075 & -0.0367\end{array}$

$0.0109 \quad 0.0713 \quad-0.0722$

$-0.0518$

$0.0958-0.0291$

$0.0577-0.0413$
1.0000

$-0.7143 \quad 1.0000$

$-0.4464 \quad 0.3685$

$0.1632-0.4783$

$-0.1327-0.1315$

$0.0097-0.0148$
1.0000

$0.0734 \quad 1.0000$

$\begin{array}{lll}0.1323 & 0.3308 & 1.0000\end{array}$

$\begin{array}{llll}-0.1169 & 0.0138 & 0.0919 & 1.0000\end{array}$ 
Table 14 VIF of expense recovery sample

15 VIF of Net Assets Recovery Sample

Funding No funds, grants, or other support was received. The authors have no relevant financial or non-financial interests to disclose.

\section{References}

Auer, J. (2006). Open and operating? An assessment of Louisiana nonprofit health and human services after Hurricanes Katrina and Rita

Bowman, W. (2011). Financial capacity and sustainability of ordinary nonprofits. Nonprofit Management and Leadership, 22(1), $37-51$.

Calabrese, T. D. (2011). Testing competing capital structure theories of nonprofit organizations. Public Budgeting and Finance, 31(3), 119-143.
Callen, J. L., Klein, A., \& Tinkelman, D. (2003). Board composition, committees, and organizational efficiency: The case of nonprofits. Nonprofit and Voluntary Sector Quarterly, 32(4), 493-520.

Carroll, D. A., \& Stater, K. J. (2009). Revenue diversification in nonprofit organizations: Does it lead to financial stability? Journal of Public Administration Research and Theory, 19(4), 947-966.

Carroll, G. R., \& Hannan, M. T. (1989). Density dependence in the evolution of populations of newspaper organizations. American Sociological Review, 54(4), 524-541.

Chang, C. F., \& Tuckman, H. P. (1994). Revenue diversification among non-profits. VOLUNTAS: International Journal of Voluntary and Nonprofit Organizations, 5(3), 273-290.

Chen, X. (2021). Are Disasters Disastrous to Nonprofit Organizations? Investigating the Financial Implications of Hurricane Sandy for Nonprofits. Nonprofit and Voluntary Sector Quarterly, 0899764021998454.

Chikoto, G. L., Sadiq, A.-A., \& Fordyce, E. (2013). Disaster mitigation and preparedness: Comparison of nonprofit, public, and private organizations. Nonprofit and Voluntary Sector Quarterly, 42(2), 391-410.

de Andrés-Alonso, P., Garcia-Rodriguez, I., \& Romero-Merino, M. E. (2015). The dangers of assessing the financial vulnerability of nonprofits using traditional measures: The case of the nongovernmental development organizations in the United Kingdom. Nonprofit Management and Leadership, 25(4), 371-382.

Donahue, A. K., \& O'Keefe, S. (2007). Universal lessons from unique events: Perspectives from Columbia and Katrina. Public Administration Review, 67, 77-81.

Froelich, K. A. (1999). Diversification of revenue strategies: Evolving resource dependence in nonprofit organizations. Nonprofit and Voluntary Sector Quarterly, 28(3), 246-268.

Frumkin, P., \& Keating, E. K. (2011). Diversification reconsidered: The risks and rewards of revenue concentration. Journal of Social Entrepreneurship, 2(2), 151-164.

Geller, S. L., Salamon, L. M., \& Mengel, K. L. (2010). Museums and other nonprofits in the current recession: A story of resilience, innovation, and survival. Journal of Museum Education, 35(2), $129-140$.

Greenlee, J. S., \& Trussel, J. M. (2000). Predicting the financial vulnerability of charitable organizations. Nonprofit Management and Leadership, 11(2), 199-210.

Grønbjerg, K. A. (1993). Understanding nonprofit funding: Managing revenues in social services and community development organizations: Jossey-Bass Inc Pub.

Guo, C., \& Acar, M. (2005). Understanding collaboration among nonprofit organizations: Combining resource dependency, institutional, and network perspectives. Nonprofit and Voluntary Sector Quarterly, 34(3), 340-361.

Hager, M. A. (2001). Financial vulnerability among arts organizations: A test of the Tuckman-Chang measures. Nonprofit and Voluntary Sector Quarterly, 30(2), 376-392.

Hung, C., \& Hager, M. A. (2019). The impact of revenue diversification on nonprofit financial health: A meta-analysis. Nonprofit and Voluntary Sector Quarterly, 48(1), 5-27.

Jegers, M., \& Verschueren, I. (2006). On the capital structure of nonprofit organisations: An empirical study for Californian organisations. Financial Accountability \& Management, 22(4), $309-329$

Joseph, C. (2011). The impact of the great recession on the financial resources of nonprofit organizations: Wilson Center for Social Entrepreneurship.

Jung, K., \& Song, M. (2015). Linking emergency management networks to disaster resilience: Bonding and bridging strategy in hierarchical or horizontal collaboration networks. Quality Quantity, 49(4), 1465-1483. 
Kapucu, N. (2006). Public-nonprofit partnerships for collective action in dynamic contexts of emergencies. Public Administration, 84(1), 205-220.

Kearns, K. (2007). Income portfolios: Alta Mira Press: Lanham. MD.

Keating, E. K., Fischer, M., Gordon, T. P., \& Greenlee, J. S. (2005). Assessing financial vulnerability in the nonprofit sector. SSRN Electronic Journal.

Lam, M., \& McDougle, L. (2016). Community variation in the financial health of nonprofit human service organizations: An examination of organizational and contextual effects. Nonprofit and Voluntary Sector Quarterly, 45(3), 500-525.

Lin, W., \& Wang, Q. (2016). What helped nonprofits weather the great recession? Evidence from human services and community improvement organizations. Nonprofit Management and Leadership, 26(3), 257-276.

Linnenluecke, M. K. (2017). Resilience in business and management research: A review of influential publications and a research agenda. International Journal of Management Reviews, 19(1), 4-30.

Markowitz, H. (1952). Portfolio selection. The. Journal of Finance, 7(1), 77-91.

McDougle, L. M., \& Lam, M. (2014). Individual- and communitylevel determinants of public attitudes toward nonprofit organizations. Nonprofit and Voluntary Sector Quarterly, 43(4), 672-692.

Meyer, A. D. (1982). Adapting to environmental jolts. Administrative Science Quarterly, 27(4), 515-537.

Never, B. (2011). Understanding constraints on nonprofit leadership tactics in times of recession. Nonprofit and Voluntary Sector Quarterly, 40(6), 990-1004.

Never, B. (2014). Divergent patterns of nonprofit financial distress. Paper Presented at the Nonprofit Policy Forum, 5(1), 67-84.

Paarlberg, L. E., An, S. H., Nesbit, R., Christensen, R. K., \& Bullock, J. (2018). A field too crowded? How measures of market structure shape nonprofit fiscal health. Nonprofit and Voluntary Sector Quarterly, 47(3), 453-473.

Park, S. E., \& Mosley, J. (2017). Nonprofit growth and decline during economic uncertainty. Human Service Organizations: Management, Leadership and Governance, 41(5), 515-531.

Pipa, T. (2006). Weathering the storm: The role of local nonprofits in the Hurricane Katrina relief effort: Aspen Institute.

Prentice, C. R. (2016a). Why so many measures of nonprofit financial performance? Analyzing and improving the use of financial measures in nonprofit research. Nonprofit and Voluntary Sector Quarterly, 45(4), 715-740.

Prentice, C. R. (2016b). Understanding nonprofit financial health: Exploring the effects of organizational and environmental variables. Nonprofit and Voluntary Sector Quarterly, 45(5), 888-909.

Qu, H. (2019). Risk and diversification of nonprofit revenue portfolios: Applying modern portfolio theory to nonprofit revenue management. Nonprofit Management and Leadership, $30(2), 193-212$.
Salamon, L. M. (2004). The state of nonprofit America: Brookings Institution Press

Salamon, L. M., Geller, S. L., \& Spence, K. L. (2009). Impact of the 2007-09 economic recession on nonprofit organizations (Communique No. 14). Retrieved from Johns Hopkins Listening Post Project. website: https://csssjhu.edu/wp-content/uploads/down loads/2011/09/LP_Communique14_2009.pdf.

Searing, E. A. M. (2018). Determinants of the recovery of financially distressed nonprofits. Nonprofit Management and Leadership, 28(3), 313-328.

Singer, J. D., \& Willett, J. B. (1993). It's about time: Using discretetime survival analysis to study duration and the timing of events. Journal of Educational Statistics, 18(2), 155-195.

Smith, S. R. (2006). Rebuilding social welfare services after Katrina: Challenges and opportunities (pp. 5-10). Public expectation and charities' response.

Smith, S. L. (2012). Coping with disaster: Lessons learned from executive directors of nonprofit organizations (NPOs) in New Orleans following Hurricane Katrina. Administration in Social Work, 36(4), 359-389.

Staw, B. M., Sandelands, L. E., \& Dutton, J. E. (1981). Threat rigidity effects in organizational behavior: A multilevel analysis. Administrative Science Quarterly, 26(4), 501-524.

Stinchcombe, A. L., \& March, J. G. (1965). Social structure and organizations. Handbook of Organizations, 7, 142-193.

Sutcliffe, K. M., \& Vogus, T. J. (2003). Organizing for resilience. Positive Organizational Scholarship: Foundations of a New Discipline, 94, 110.

Sylves, R. (2008). Public managers, volunteer organizations, and disasters. Public Management Review, 37(4), 76.

Trussel, J. M. (2002). Revisiting the prediction of financial vulnerability. Nonprofit Management and Leadership, 13(1), 17-31.

Tuckman, H. P., \& Chang, C. F. (1991). A methodology for measuring the financial vulnerability of charitable nonprofit organizations. Nonprofit and Voluntary Sector Quarterly, 20(4), $445-460$.

Wicker, P., \& Breuer, C. (2013). Understanding the importance of organizational resources to explain organizational problems: Evidence from nonprofit sport clubs in Germany. VOLUNTAS: International Journal of Voluntary and Nonprofit Organizations, 24(2), 461-484.

Wu, V. C. S. (2021). The geography and disparities of community philanthropy: A community assessment model of needs, resources, and ecological environment. VOLUNTAS: International Journal of Voluntary and Nonprofit Organizations, 32(2), $351-371$

Young, D. R. (2007). Toward a normative theory of nonprofit finance. Financing Nonprofits: Putting Theory into Practice, 339-372.

Publisher's Note Springer Nature remains neutral with regard to jurisdictional claims in published maps and institutional affiliations. 